УДК: 376.42

https://doi.org/10.52058/2786-4952-2021-5(5)-417-428

Косенко Юрій Миколайович кандидат педагогічних наук, доцент кафедри спеціальної та інклюзивної освіти, Сумський державний педагогічний університет імені А. С. Макаренка, вул. Інтернаціоналістів, 41/40, м. Суми, 40005, тел.: (050) 838-78-18, e-mail: kosenko75@ gmail.com, https://orcid.org/0000-0003-2723-2031

\title{
ФОРМУВАННЯ СУСПІЛЬСТВОЗНАВЧИХ ЗНАНЬ У ДІТЕЙ 3 ПОРУШЕННЯМИ ІНТЕЛЕКТУАЛЬНОГО РОЗВИТКУ В УКРАЇНІ В 80-Х РОКАХ ХХ СТОЛІТТЯ
}

Анотація. У статті висвітлено комплексний історико-ретроспективний аналіз розвитку спеціальної методики навчання суспільствознавчим дисциплінам учнів з інтелектуальними порушеннями в Україні в 80-х роках минулого століття. Опрацьовано та висвітлено дослідження В. Бондаря, К. Баранова, О. Зогіної, А. Капустіна, Ю. Кузнєцова, В. Лапшина, С. Ніколаєва, Г. Плешканівської, Б. Пузанова та інших, які в означений хронологічний період розв'язували проблему підвищення ефективності навчання історії та основам правознавства у спеціальних закладах середньої освіти. Описані концептуальні погляди вчених-дефектологів, висвітлені запропоновані ними способи формування суспільствознавчих уявлень і понять у школярів із порушеннями інтелекту, використання наочних методів, самостійного опрацювання історичного та правознавчого матеріалу, формування хронологічних та просторових уявлень, причинно-наслідкових зв'язків тощо. Наведені методичні рекомендації щодо застосування на уроках зазначеного дидактичного інструментарію вчителями-дефектологами.

Відзначено елементарність та значну заідеологізованість шкільного курсу історії та розділу «Наша Радянська держава. Права та обов’язки радянських громадян» в курсі історії СРСР та окремого курсу «Бесіди про радянське суспільство, права та обов'язки громадян».

Наголошено на впливі шкільних предметів суспільствознавчого змісту на формування світогляду й моральних принципів i переконань у дітей 3 інтелектуальними порушеннями.

Підкреслено складність опрацювання учнями суспільствознавчого матеріалу, насиченість означених курсів складними поняттями та категоріями.

Наголошено на відсутності в досліджуваному хронологічному періоді спеціально розроблених для школярів з порушеннями інтелекту підручників, зошитів, атласів, контурних карт та іншого дидактичного матеріалу. У статті висвітлено провідні та найбільш ефективні у той час дидактичні методи, прийоми, засоби та форми навчання дітей зазначеної категорії навчальному матеріалу суспільствознавчого змісту. 
Журнал«Герспективита іновації науки»

(Серія «Гедагогіка», Серія«ГТихологія», Серія«Медицина»

№5(5) 2021

Ключові слова: учні 3 порушеннями інтелектуального розвитку, навчальний матеріал суспільствознавчого змісту, історико-ретроспективний аналіз.

Kosenko Yuriy Mykolayovych Candidate of Pedagogical Sciences, Associate Professor of the Department of Special and Inclusive Education, Sumy State Pedagogical University named after AS Makarenko, Nternationalists St., 41/40, Sumy, 40005, tel.: (050) 838-78-18, e-mail: kosenko75@gmail.com, https://orcid.org/0000-0003-2723-2031

\title{
FORMATION OF SOCIAL SCIENCE KNOWLEDGE IN SCHOOLCHILDREN WITH MENTAL DEVELOPMENT DISORDER IN UKRAINE IN THE 80-S OF THE XX CENTURY
}

\begin{abstract}
The article highlights a comprehensive historical and retrospective analysis of the development of special methods of teaching social science disciplines to schoolchildren with intellectual disabilities in Ukraine in the 80s of last century. The researches of V. Bondar, K. Baranov, O. Zogina, A. Kapustin, Y. Kuznetsov, V. Lapshin, S. Nikolaev, G. Pleshkanovskaya, B. Puzanov and others which in the specified chronological period solved the problem of improving the effectiveness of teaching history and the basics of law in special institutions of secondary education. The conceptual views of defectologists are described, their methods of forming social science ideas and concepts in schoolchildren with intellectual disabilities, the use of visual methods, self-study of historical and legal material, the formation of chronological and spatial ideas, causation and more. Methodical recommendations on the use of the specified didactic tools in the lessons by teachers-defectologists are given.
\end{abstract}

Described the elementary and significant ideological nature of the school history course and the section «Our Soviet state. Rights and Duties of Soviet Citizens» in the course of the history of the USSR and a separate course «Discussions on Soviet society, rights and responsibilities of citizens».

The influence of school subjects of social science content on the formation of worldview and moral principles and beliefs in children with intellectual disabilities is emphasized.

The complexity of schoolchildren study of social science material, the saturation of these courses with complex concepts and categories are emphasized.

The absence in the studied chronological period is emphasized textbooks, exercise books, atlases, contour maps and other didactic material specially designed for schoolchildren with intellectual disabilities. The article highlights the leading and most effective at the time didactic methods, techniques, tools and forms of teaching children in this category of educational material of social science content.

Keywords: schoolchildren with intellectual disabilities, educational material of social science content, historical-retrospective analysis. 
Постановка проблеми. Кінець минулого століття характеризується значним інтересом науковців i методистів до проблеми підвищення ефективності засвоєння навчального матеріалу школярами 3 порушеннями інтелектуального розвитку. Особливої уваги заслуговують роботи вітчизняних і закордонних дослідників, які приділяли увагу розвитку мотивації та інтересу, свідомому оволодінню теоретичними знаннями та практичними уміннями 3 навчальних курсів суспільствознавчого змісту.

Значна кількість робіт дослідників присвячена підвищенню ефективності навчанню історії та основам правознавства школярів означеної категорії, диференціації навчального матеріалу для дітей з різними пізнавальними та психофізичними можливостями.

Не дивлячись на активний розвиток цифрових технологій у наш час та їх широке впровадження в освітньо-корекційному процесі, низка методів, форм і засобів можуть бути корисними для сучасних педагогів-практиків. Ретроспективне вивчення шляхів ефективного формування суспільствознавчих знань у дітей із порушеннями інтелекту в 80 -х роках XX століття дозволить більш глибше зрозуміти методологію спеціальної дидактики, що $є$ важливим чинником у розробці новітніх підходів до навчання школярі із порушеннями інтелекту предметам суспільствознавчого змісту.

Аналіз останніх досліджень і публікацій. У 80 -х роках минулого століття активно розробляли різноманітні концептуальні підходи шкільної дидактики провідні науковці $\quad$ CPCP: $\quad$ В. Давидов, Д. Ельконін, П. Гальперін, Н. Менчинська, М. Скаткін, Б. Ссіпов, М. Дайрі та інші.

Проблемою підвищення ефективності навчання школярів з порушеннями інтелекту в 80-х роках XX століття займалися В. Бондар, Л. Вавіна, I. Єременко, Г. Мерсіянова, В. Синьов та інші.

Розробляли та впроваджували ефективні прийоми та засоби навчання дітей зазначеної категорії на уроках історії в спеціальних закладів середньої освіти такі науковці, як В. Бондар, К. Баранов, О. Зогіна, А. Капустін, Ю. Кузнєцов, В. Лапшин, С. Ніколаєв, Г. Плешканівська, Б. Пузанов та інші.

Ці дослідження стосувалися окремих способів формування суспільствознавчих уявлень і понять у дітей 3 порушеннями інтелекту, використання наочних методів навчання в роботі з означеними дітьми, самостійного опрацювання суспільствознавчого матеріалу, формування хронологічних та просторових уявлень, причинно-наслідкових зв'язків тощо.

Позитивне значення у становленні та розвитку спеціальної методики викладання суспільствознавчих предметів на території України у 80-х роках XX століття відіграла доступність українським вчителям-дефектологам до науково-методичних і практичних розробок колег з усього Радянського Союзу через всесоюзні засоби масової інформації.

Мета статті - дослідження особливостей та механізмів формування суспільствознавчих знань у дітей з порушеннями інтелектуального розвитку в Україні в 80 -х роках XX століття. 
Журнал«Герспективитаінновації наукиљ

(Серія«Гедагогіка»), Серія«ГТихологія», Серія «Медицина»

№5(5) 2021

Виклад основного матеріалу. На початку 80 -х років XX століття методика навчання предметам суспільствознавчого змісту в спеціальних навчальних закладах (у той час це були допоміжні школи) отримала свій подальший розвиток. Суспільствознавчі знання діти з порушеннями інтелекту в цей хронологічний період отримували переважно з уроків історії. Також у 8му класі школярі цієї категорії знайомилися з основами правових знать (в межах окремого розділу курсу історії СРСР).

У рамках цієї навчальної дисципліни учням повідомлялися найбільш значні історичні події, які мали виховне значення та ідеологічний вплив на формування особистості школяра зазначеного періоду.

Аналіз навчальної програми з історії свідчить про провідну роль наочних методів навчання та їхнє комбіноване використання з іншими дидактичними методами в освітньо-корекційному процесі тогочасної спеціальної школи. Розробники програми рекомендували активно використовувати технічні засоби навчання для демонстрації школярам уривків кінофільмів, діафільмів, слайдів тощо [1;2].

Низка робіт присвячених ефективному засвоєнню суспільствознавчого матеріалу учнями спеціальних шкіл у 80 -х роках $\mathrm{XX}$ століття належить Г. Плешканівській. Згідно концепції дослідниці, розумова активність школярів відбувається у двох аспектах: відтворенні знань, одержаних в готовому вигляді від вчителя та самостійна діяльність, яка спрямована на здобуття знань, їх усвідомлення та застосування.

Особливу увагу вчена відводила самостійному вивченню дітьми минулого країни. Зокрема, Г. Плешканівська наголошувала на індивідуалізованій самостійній роботі школярів із порушеннями інтелекту, а саме, пристосуванні навчальної роботи до індивідуальних особливостей учнів цієї категорії.

Вчена підкреслювала важливість використання різних за ступенем складності варіантів завдань. Основним правилом, яким повинен користуватися вчитель, на думку дослідниці, повинно стати «введення в самостійну роботу лише того, що учні вже вміють робити» [3].

Науковцем було диференційовано самостійну роботу на такі види:

a) робота для одержання нових знань;

б) застосування знань;

в) повторення і перевірка знань, умінь і навичок.

Для формування вміння самостійно працювати з історичною картою, на думку Г. Плешканівської, потрібно вчити учнів орієнтуватися на карті, правильно i швидко розбиратися в умовних позначеннях, пов'язувати відомості карти 3 текстом підручника, правильно записувати історичну інформацію тощо.

Г. Плешканівська вважала ефективними такі види роботи, як підготовка відповідей на основі прочитаного тексту, вибіркове читання за завданнями вчителя, самостійне читання, читання про себе, словникова робота, складання 
плану оповідання, розповідь за планом, знаходження головної думки в тексті, оповідання за малюнком тощо.

Також дослідниця вважала ефективними методами й прийомами формування елементарних суспільствознавчих знань у школярів 3 порушеннями інтелекту такі, як: чіткість розповіді, виділення головного, запис на дошці з дублюванням у зошитах нових термінів, дат, назв, імен, висновків. На переконання вченої, важливими видами діяльності на уроках історії $\epsilon$ робота 3 підручником, робота 3 історичними документами, художньою літературою та періодикою.

Щодо роботи школярів із історичними документами, то Г. Плешканівська вважала, що ретельного підбору матеріалів замало. Необхідно до історичних уривків застосовувати коментоване читання. Також автор пропонувала використовувати поєднання читання тексту з аналізом документу. Під час аналізу діти повинні своїми словами давати відповіді, посилаючись на окремі місця 3 документа. Важливо враховувати і загальний розвиток учнів, навички читання, наявність у них практичних умінь і навичок.

Узагальнюючи погляди Г.Плешканівської зазначимо, що вчена розглядала самостійну роботу школярів 3 порушеннями інтелекту на уроках iсторії, як важливий навчально-виховний i корекційний інструмент соціалізації осіб цієї категорії. Основними вимогами організації та проведення самостійної роботи в спеціальних закладах середньої освіти є: систематичне залучення школярів до таких видів діяльності; врахування рівня пізнавальних можливостей при розробленні завдань самостійної роботи; використання самостійної роботи учнів з підручником, картою, художньою літературою тощо; урізноманітнення та варіативність завдань; введення до самостійної роботи раніше вивченого матеріалу; керівництво процесом самостійного виконання учнями завдань та контроль якості зробленої роботи; використання письмових самостійних робіт (складання планів i схем, відповідей на запитання, заповнення таблиць тощо).

На нашу думку, достатньо багато запропонованих Г. Плешканівською методів і прийомів вивчення суспільствознавчого матеріалу школярами 3 порушеннями інтелектуального розвитку будуть корисними у роботі і в наш час.

У середині 80-х років XX століття шкільний курс історії, як провідна суспільствознавча навчальна дисципліна, стає одним із основних інструментів формування громадянської позиції особистості. Історичний матеріал використовувався у класній, позакласній і позашкільній ідейно-політичній роботі.

У цей період В. Бондар та Г. Плешканівська продовжують проводити активну дослідницьку роботу в сфері підвищення ефективності вивчення суспільствознавчого матеріалу школярами із порушеннями інтелекту. Науковці визначили причини труднощів засвоєння історичного матеріалу дітьми цієї категорії. Вченими було відмічено своєрідність мислення дітей 3 
порушеннями інтелекту, яке проявляється в недорозвиненні аналітикосинтетичних функцій. Науковці наголошували на тому, що якість засвоєння суспільствознавчого матеріалу такими учнями визначається не лише особливостями їх пізнавальної діяльності, але й методами, які використовуються у процесі навчання дітей.

На думку В.Бондаря та Г.Плешканівської, значне місце в засвоєнні суспільствознавчого матеріалу дітьми відіграє розповідь вчителя. За авторами, розповідь повинна відповідати ідейному задуму вчителя; вміщувати історичні факти, оцінки, висновки, узагальнення; мати чітку логічну структуру; співвідноситися з текстом підручника, але за змістом не бути тотожною з ним.

Дослідники рекомендували використовувати при вивченні суспільствознавчого матеріалу повідомлення, опис, пояснення, міркування та бесіди. Значна увага приділялася бесіді. В.Бондар і Г. Плешканівська розробили вимоги до бесіди в роботі з учнями із порушеннями інтелекту. На нашу думку, до найбільш важливих відносяться такі: запитання повинні бути зрозумілі й доступні учню; запитання потрібно ставити перед усім класом, а не перед одним учнем; запитання повинні сприяти учню знайти помилку; запитання повинні бути суттєвими, стосуватися істотних ознак історичних процесів і явищ; запитання повинні бути дидактично простими; запитання повинні бути послідовними, кожне наступне повинно бути логічним продовженням попереднього та інші.

В. Бондар і Г. Плешканівська наголошували на важливості повторення одних i тих самих за змістом запитань у зміненій формі. Це на їхнє переконання буде сприяти активізації розумової діяльності школярів із порушеннями інтелекту [4].

Як бачимо, В. Бондар і Г. Плешканівська розглядали процес формування суспільствознавчих знань i вмінь у школярів із порушеннями інтелекту комплексно, через підготовку вчителів до уроків історії 3 врахуванням особливостей інтелектуального та психофізичного розвитку дітей цієї категорії та використанням і поєднанням найбільш ефективних дидактичних методів і прийомів.

Дослідження В. Бондаря та Г. Плешканівської відіграло важливе значення у розвитку вітчизняної теорії та практики навчання суспільствознавчим матеріалам учнів із порушеннями інтелекту. Науковці описали особливості засвоєння історичного матеріалу школярами означеної категорії, розкрили методи та прийоми навчання таких учнів, описали послідовність їх використанням і надали велику кількість рекомендацій.

Важливе значення у другій половині 80-х років минулого століття відводилося свідомому засвоєнню учнями історичної хронології та їхній орієнтації у часі. Розв'язаннями цієї проблеми зайнявся В. Лапшин. Вчений зазначав, що у зв'язку із особливостями пізнавальної діяльності дітей зазначеної категорії, порушеннями в них словесно-логічної та аналітикосинтетичної форм мислення, питання усвідомлення історичного часу i 
співвідношення подій минулого із історичною хронологією (встановлення причинно-наслідкової та часової залежності) $\epsilon$ найбільш складними та вимагають спеціальних методичних прийомів. Науковець пропонував поетапне розв’язання цієї проблеми. Зокрема, В. Лапшин виокремлював такі етапи: усвідомлення дітьми понять «давно», «недавно», «до», «після», «століття»; визначення дати історичної події 3 точністю до чверті століття (перша, друга, третя, четверта чверті); співставлення історичних дат (раніше пізніше).

Дослідник запропонував простий, але ефективний спосіб визначення століття школярами 3 порушеннями інтелекту. Для цього потрібно поділити будь-яку дату на дві частини (наприклад, 1147 р.= 11 та 47), визначити ту пару цифр яка позначає століття та додати до неї одиницю $(11+1=12)$. Відповідь означатиме століття до якого належить дата (1147 р. - 12 ст.) [5].

Також В. Лапшину належить унікальна класифікація історичних понять. Вчений не відкидав існуючої класифікації понять, але за критерій взяв рівень засвоєння історичних понять школярами $з$ порушеннями інтелекту.

До першої групи він відносив поняття, які відображають конкретні історичні об'єкти та які мають опору на наочно-чуттєвий досвід дитини (пам’ятники матеріальної культури, що можна спостерігати в натуральному вигляді чи побачити їх фотографії, макети). Рівень засвоєння цих понять, за даними дослідника, становить - $90 \%$.

Друга група - це поняття, які відображають майнові та соціальні відношення людей, а також пов'язані з ними різні види діяльності. Рівень засвоєння таких понять становить $-60 \%$.

До третьої групи вчений відносив поняття, які характеризують тип влади, політичний лад, систему суспільних відносин. Ці поняття засвоює близько 45 \% школярів із порушеннями інтелекту.

Четверта група - це поняття суспільствознавчого характеру (клас, держава, державний лад тощо). Ці поняття мають найбільш високий рівень узагальнення і лише 20 \% учнів спеціальної школи здатні усвідомити їх.

Окрему підгрупу суспільствознавчих понять, на думку Б. Пузанова, складають ті, які є основою правового навчання і виховання старшокласників i3 порушеннями інтелекту. Результати його досліджень свідчать, що використання правових уявлень і понять в учнів цієї категорії носять переважно випадковий, безсистемний характер. Оцінка власних або інших вчинків у таких осіб, як правило, неадекватна. Причиною цьому науковець вбачає складність пошуку дітьми причинно-наслідкових відношень. Б. Пузанов пропонував більше часу відводити на визначення логічних взаємозв'язків між історичними та суспільними процесами і явищами, на усвідомлення морально-етичних категорій під час вивчення елементів адміністративного та карного законодавства у межах розділу «Наша Радянська держава. Права та обов'язки радянських громадян» в курсі історії СРСР та окремого курсу «Бесіди про радянське суспільство, права та обов'язки 
громадян» (цей курс викладався лише у тих допоміжних школах, у яких були 9-ті класи).

Для міцного засвоєння суспільствознавчих понять, Б. Пузанов рекомендував цілеспрямовано формувати у дітей знання-переконання, які визначають правову свідомість індивіда та соціальні норми його поведінки. Вчений розробив змістове наповнення правового навчання для старших (8-9) класів допоміжної школи, що забезпечило комплексне та раціональне поєднання шкільних і позашкільних форм роботи [5].

Схожі дослідження проводив А. Капустін. Він вивчав шляхи підвищення продуктивності формування історичних та суспільствознавчих понять у школярів з порушеннями інтелекту. Науковець звертав увагу на корекційну спрямованість цього процесу. На його думку, необхідно більше приділяти уваги формуванню тих суспільствознавчих понять, які матимуть важливе значення для соціальної адаптації цих дітей; систематизовувати суспільствознавчий матеріал i визначати пріоритети; працювати над збільшенням кількості суттєвих ознак суспільствознавчих понять на основі різноманітності дидактичного та наочного матеріалу (картки, малюнки, історичні карти тощо) [6].

У середині 80-х років ХХ століття було вперше визначено типи уроків історії, які застосовувалися у допоміжній школі, та їх структура. До цих пір вчителі історії користувалися класифікацією, розробленою для масових навчальних закладів. Розробив цю класифікацію - Ю. Кузнєцов. Він виділяв вступний урок, комбінований урок, урок повідомлення нових знань, заключний урок, повторювально-узагальнюючий урок, урок контролю та обліку знань.

Ю. Кузнєцов також виділив три основних частини уроку суспільствознавчого змісту: підготовчу, основну та заключну. Підготовча частина складалася із організаційного моменту, перевірки домашнього завдання, попередньої бесіди, яка підводила дітей до сприйняття нової теми. На основній частині проводилося повідомлення теми уроку, повідомлявся новий матеріал, проводилася робота із закріплення та формування необхідних вмінь і навичок у школярів. На заключній частині уроку підводилися підсумки уроку, проводився інструктаж з виконання домашнього завдання, оцінювалася діяльність учнів та відбувалося організоване закінчення уроку.

Узагальнюючи вимоги до уроку історії у допоміжній школі, Ю. Кузнєцов відмічав, що, незалежно від типу заняття, теми уроку, кількості дітей у класі, новий матеріал учні повинні засвоювати на уроці, а це можливо лише за відповідності заняття всім необхідним вимогам. До цих вимог, дослідник відносив: науковість суспільствознавчого матеріалу, чітке планування мети i завдань уроку, зв'язок кожного уроку з попереднім і наступним, доцільний вибір методичних прийомів, засобів i методів навчання, поєднання колективної, групової та індивідуальної роботи, організаційна чіткість уроку, створення емоційної, творчої атмосфери, розвиток пізнавальних інтересів у 
дітей, використання краєзнавчого матеріалу на уроці тощо [7].

З 1986 року допоміжна школа реорганізується у дев'ятирічну. Вивчення суспільствознавчого матеріалу школярами 3 порушеннями інтелекту відбувалося, переважно, на уроках історії. 3 цим навчальним предметом діти починали знайомитися з 7-го класу. Нова програма 3 історії не передбачала кардинальних змін. Термін вивчення історії у допоміжній школі залишався не змінним - 3 7-го по 9-й класи. У навчальній програмі в якості найбільш ефективних методів пропонувалося використовувати наочність, слово вчителя, бесіди зі школярами.

У другій половині $80-\mathrm{x}$ років $\mathrm{XX}$ століття набуває популярності концепція I. Сременка щодо диференційованого навчання учнів із порушеннями інтелекту, типів і структури допоміжного навчання, які не мали аналогів у корекційній педагогіці.

Проведений під керівництвом I. Сременка педагогічний експеримент засвідчив, що у кожному класі допоміжної школи навчаються діти з різним рівнем розвитку пізнавальних можливостей, що зумовлює різну готовність як до шкільного навчання так і до засвоєння одного і того ж навчального матеріалу. Це обумовило необхідність введення у допоміжних школах в кінці 80-х років диференційованого навчання, в тому числі й на уроках суспільствознавчого змісту [8].

Варто зазначити, що певний вплив на розвиток методичних поглядів вчителів предметів суспільствознавчого змісту допоміжних шкіл тогочасної України мали роботи науковців з інших республік СРСР (К. Баранов, О. Зогіна та інші).

Зокрема, К. Баранов підкреслював, що в умовах традиційного навчання сформовані у дітей суспільствознавчі знання відрізняються недостатньою об'єктивністю, системністю, повнотою та динамічністю. На його переконання, саме вивчення конкретного матеріалу про суспільні відношення у різні історичні епохи сприяє усвідомленому сприйняттю правових понять учнями 3 порушеннями інтелекту. Дослідник пропонував використовувати спеціальні наочні опори для формування низки загальних понять, які виступають засобом свідомого засвоєння знань про окремі суспільно-політичні явища та факти. За задумом вченого, спеціально розроблені словесно узагальнені конструкції повинні виступати інструментом формування таких важливих понять, як «суспільство», «суспільні класи», «закон», «влада», «держава» тощо [9].

Значний внесок у організацію науково-дослідної та теоретико-методичної роботи у галузі навчання предметам суспільствознавчого змісту здійснила О. Зогіна. Вчена досліджувала особливості використання образної наочності при формуванні суспільствознавчих понять у старших класах допоміжної школи. Науковець розробила методику використання наочних посібників, сутність якої полягала в поетапному використанні сюжетної картини, роботі з опорними термінами, бесіді за змістом картини на основі запитань вчителя, самостійних розповідей учнів із застосуванням зразків розповідей і плану вчителя; 
О. Зогіна пропонувала раціонально поєднувати словесні та наочні прийоми навчання, а саме: варіювання завдань 3 поступовим ускладненням застосування суспільствознавчих понять; огляд картини - бесіда за картиною - створення розповіді по картині з використанням зразка розповіді вчителя створення самостійної розповіді за планом вчителя; створення розповіді із застосуванням опорної термінології; перенесення понять у схематичні зображення; замальовка важливих фрагментів картини - висновки по картині.

За даними дослідниці, поєднання прийомів словесної діяльності із безпосереднім сприйняттям картин, схем, замальовок, аплікацій дозволяє успішно формувати суспільствознавчі поняття в старшокласників із порушеннями інтелекту [10].

Висновки. Підсумовуючи стан формування суспільствознавчих знань у дітей із порушеннями інтелектуального розвитку в Україні в 80-х роках XX століття зауважимо, що провідним навчальним предметом, на якому діти засвоювали суспільствознавчі поняття та формували відповідні предметні вміння був курс історії СРСР. Зміст цього курсу в допоміжній школі носив яскраво виражений ідеологічний характер. У 80-х роках інтерес до зазначеної проблеми в наукових колах значно збільшується. 3'являються дослідження В. Бондаря, К. Баранова, О. Зогіної, А. Капустіна, Ю. Кузнєцова, В. Лапшина, С. Ніколаєва, Г. Плешканівської, Б. Пузанова та інших. У їхніх роботах розкриваються способи формування суспільствознавчих уявлень і понять у школярів iз порушеннями інтелекту, використання наочних методів, самостійного опрацювання історичного та правознавчого матеріалу, формування хронологічних та просторових уявлень, причинно-наслідкових зв'язків тощо.

Зауважимо, що не дивлячись на велику теоретичну та практичну цінність досліджень, комплексного підходу у вивченні цієї проблеми не було. У цей період не було розроблено підручників з історії для дітей цієї категорії, не було атласів i контурних карт із суспільствознавчих курсів, не існувало методичних посібників для вчителів-дефектологів 3 викладання суспільствознавчих предметів у допоміжній школі.

\section{Лimepamypa:}

1. Косенко Ю. М. Становлення та розвиток спеціальної методики навчання історії (друга половина XIX - початок XXI століть) : монографія. / Ю. М. Косенко. - Чернівці : Букрек, 2016. - 216 с.

2. Косенко Ю. М. Розвиток теорії та практики навчання історії розумово відсталих дітей в Україні (кінець XIX - початок XX століть) / Ю. М. Косенко, В. С. Бугрій // Освіта осіб з особливими потребами: шляхи розбудови. - 2016. - Вип. 11. - С. 37-43.

3. Методичні рекомендації до організації самостійної роботи учнів на уроках історії в допоміжних школах / укладач Г. М. Плешканівська. - К.: РУМК, 1981. - 43 с.

4. Методичні рекомендації щодо удосконалення процесу навчання на уроках історії у допоміжній школі / уклад. В. І. Бондар, Г. М. Плешканівська. - К.: РУМК, 1985. -48 с.

5. Лапшин В. А., Особенности усвоения исторического и обществоведческого материала учащимися VI - VIII классов вспомогательной школы / В. А. Лапшин, Б. П. Пузанов // Дефектология. - 1986. - № 1. - С. 52-57. 
6. Капустин А. И. Исследование уровня сформированости исторических понятий у учащихся II-V классов вспомогательной школы / А. И. Капустин // Дефектология. - 1989. № 4. - С. 33-37.

7. Этапы подготовки к уроку истории во вспомогательной школе : методические рекомендации для студентов и учителей / сост. Ю. Ф. Кузнецов. - Свердловск: СГПИ, 1984. - 18 c.

8. Єременко І. Г. Диференційоване навчання в допоміжній школі / I. Г. Сременко, Л. С. Вавіна, Г. М. Мерсіянова. - К. : Радянська школа, 1979. - 142 с.

9. Баранов К. В. Педагогический рисунок на уроках истории во вспомогательной школе. Методические рекомендации / К. В. Баранов. - Минск : РИУУ, 1988. 18 с.

10. Зогина О. Г. Некоторые методические приемы работы с сюжетной картиной на уроке истории в старших класах вспомогательной школы / О. Г. Зогина // Актуальные проблемы теории и практики дефектологи. - М., 1990. С. 2 -29.

\section{References:}

1. Kosenko, Yu. M. (2016). Stanovlennia ta rozvytok spetsialnoi metodyky navchannia istorii (druha polovyna XIX - pochatok XXI stolit) [Formation and development of special methods of teaching history (second half of the XIX - early XXI centuries)]. Chernivtsi: Bukrek. [in Ukrainian].

2. Kosenko, Yu. M., \& Buhrii, V. S. (2016). Rozvytok teorii ta praktyky navchannia istorii rozumovo vidstalykh ditei v Ukraini (kinets XIX - pochatok XX stolit) [Development of theory and practice of teaching the history of mentally retarded children in Ukraine (late XIX - early XX centuries)]. Osvita osib z osoblyvymy potrebamy: shliakhy rozbudovy - Education of people with special needs: ways of development. 11, 37-43 [in Ukrainian].

3. Pleshkanivska, H. M. (Eds.). (1981). Metodychni rekomendatsii do orhanizatsii samostiinoi roboty uchniv na urokakh istorii $\mathrm{v}$ dopomizhnykh shkolakh [Methodical recommendations for the organization of independent work of students in history lessons in auxiliary schools. Kyiv: RUMK [in USSR].

4. Bondar, V. I., \& Pleshkanivska, H. M. (Eds.). (1985). Metodychni rekomendatsii shchodo udoskonalennia protsesu navchannia na urokakh istorii u dopomizhnii shkoli [Methodical recommendations for improving the learning process in history lessons in the auxiliary school. Kyiv: RUMK [in USSR].

5. Lapshyn, V. A., \& Puzanov, B. P. (1986). Osobennosty usvoenyia ystorycheskoho y obshchestvovedcheskoho materyala uchashchymysia VI - VIII klassov vspomohatelnoi shkolb [Features of assimilation of historical and social science material by students of VI - VIII classes of auxiliary school]. Defektolohyia - Defectology, 1, 52-57 [in USSR].

6. Kapustyn, A. Y. (1989). Yssledovanye urovnia sformyrovanosty ystorycheskykh poniatyi u uchashchykhsia II-V klassov vspomohatelnoi shkolы [Research of the level of formation of historical concepts in students of II-V classes of auxiliary school]. Defektolohyia-Defectology, 4, 33-37 [in USSR].

7. Kuznetsov, Yu. F. (Eds.). (1984). Эtapы podhotovky k uroku ystoryy vo vspomohatelnoi shkole: metodycheskye rekomendatsyy dlia studentov y uchytelei [Stages of preparation for a history lesson in an auxiliary school: guidelines for students and teachers. Sverdlovsk: SHPY [in USSR].

8. Yeremenko, I. H., Vavina L. S., \& Mersiianova H. M. (1979). Dyferentsiiovane navchannia $\mathrm{v}$ dopomizhnii shkoli [Differentiated education in an auxiliary school]. Kyiv: Radianska shkola [in USSR].

9. Baranov, K. V. (1988). Pedahohycheskyi rysunok na urokakh ystoryy vo vspomohatelnoi shkole. Metodycheskye rekomendatsyy [Pedagogical drawing in history lessons at the auxiliary school. Methodical recommendations]. Mynsk: RYUU [in USSR]. 
10. Zohyna, O. H. (1990). Nekotorыe metodycheskye pryemы rabotы s siuzhetnoi kartynoi na uroke ystoryy $\mathrm{v}$ starshykh klasakh vspomohatelnoi shkolы [Some methodological techniques for working with a plot picture in a history lesson in the senior classes of an auxiliary school]. Aktualnble problembl teoryy y praktyky defektolohy - Actual problems of theory and practice defectologists.(pp. 2-29). Moscow [in USSR]. 